\title{
Alpine Younger Dryas glaciers as palaeo-precipitation gauges
}

\author{
Hanns Kerschner, Georg Kaser, Rudolf Sailer \\ Institut für Geographie, Universität Innsbruck, Innrain 52, A-6020 Innsbruck, Austria
}

\begin{abstract}
Moraines of the Younger Dryas "Egesen Stadial", which are widespread features in the Alps, are a valuable terrestrial data source for quantitative palaeoclimatic studies. The depression of the early Younger Dryas (Egesen-I) equilibrium-line altitude (ELA) shows a distinct spatial pattern. It was greatest (about -450 to $-500 \mathrm{~m}$ vs present day) in areas exposed towards the west and northwest. In the central, more sheltered valleys, it was on the order of $-300 \mathrm{~m}$ or less. Summer temperature depression, which can be derived from the Younger Dryas timberline depression, was on the order of $-3.5 \mathrm{~K}$. The stochastic glacier-climate model of Ohmura and others (1992), which relates summer temperature and precipitation at the ELA, is used to infer precipitation change. Results are compared with those obtained from the glacial-meteorological approach of Kuhn (1981a). The two models produce highly similar results. During the early Younger Dryas, climate in the central valleys of the Alps seems to have been considerably drier than today. In areas open to the west and northwest, precipitation seems to have been the same as today or even slightly higher. These results, which are based on a rather dense network of data points, agree well with results from permafrost-climate studies and the more qualitative information from palaeobotanical research. They also support the results from atmospheric general circulation models for the Younger Dryas in Europe, which point towards a more zonal type of circulation.
\end{abstract}

\section{INTRODUCTION}

Moraines of the Younger Dryas "Egesen Stadial" are conspicuous features in many parts of the Alps. The abundant geomorphological record from this period of time is a valuable terrestrial palaeoclimatic archive, because it is sufficiently extensive to allow a detailed and accurate reconstruction of the former glacier topographies. In this paper we offer some perspectives from quantitative palaeoglaciologic and palaeoclimatic interpretation of that record using simple statistical and glacial-meteorological glacierclimate models. This work continues that of Kerschner (1981, 1985), Kuhn (1981b) and Maisch and Haeberli (1982), using a much larger database. Depressions of the equilibrium-line altitude (ELA) and timberline (TL) are the principal input data. The main focus will be on early Younger Dryas precipitation patterns in the northern and central Alps. These may serve as a check for the results from atmospheric general circulation models (AGCMs) for the Younger Dryas (Isarin and others, 1997; Renssen, 1997), because regional precipitation patterns in the Alps are closely linked to synoptic-scale airflow patterns (Fliri and Schüepp, 1983).

\section{METHODS}

The Late-glacial moraine sequence ("stadials") has been extensively mapped in both the Austrian and Swiss Alps (e.g. Heuberger, 1966; Mayr and Heuberger, 1968; Kerschner 1978; Furrer and others, 1987 and references therein). The moraines of the "Egesen Stadial" are the most marked and widespread of the series. In many valleys, three and sometimes four distinct sets of moraines can be found (Egesen-I to Egesen-III, Kromer/Kartell), representing the last cold event prior to the many advances of Holocene age, which characteristically reached only the Little Ice Age (LIA) extent (e.g. Patzelt and Bortenschlager, 1973; Holzhauser, 1984). Basal radiocarbon dates from peat bogs and the results from pollen analysis in the tongue areas of Egesen moraines are in the late Younger Dryas-early Preboreal time range (e.g. Patzelt, 1972; Müller and others, 1981; Bortenschlager, 1984; Furrer and others, 1987; Burga and Perret, 1998). Surface exposure ages of an Egesen-I moraine at Julier pass, Switzerland, show that it was deposited a few centuries after the onset of the Younger Dryas (Ivy-Ochs and others, 1995, 1996).

ELAs are determined using an accumulation-area ratio of 0.67 and are normally considered reliable within $\pm 20 \mathrm{~m}$. For practical reasons, ELA depressions ( $\triangle$ ELAs) are calculated relative to the weighted mean of the Little Ice Age (1850) ELA in the respective catchments (Groß and others, 1977). For a comparison with modern (1931-60) climatic data, it is assumed that the "modern" (mid-20th-century) ELA is $100 \mathrm{~m}$ higher. For the purpose of this paper, this seems to be a reasonable mean value for average-sized glaciers in the Alps (Groß, 1987; Maisch, 1992). The $\Delta$ ELA values of the Egesen-I advance used in this paper were taken from our own fieldwork and from the literature (see Appendix). They show a characteristic spatial pattern with highest values $(-400$ to $-500 \mathrm{~m}$ vs modern values) at the northern and western margins of the eastern Alps (e.g. western Silvretta mountains, Zugspitze and the Karwendel massif), and lowest values $(-300$ to $-280 \mathrm{~m})$ in the well-sheltered central valleys of the Alps (e.g. western Ötztal mountains, upper Engadine). The gradient from areas with large $\triangle \mathrm{ELA}$ values to those with 
smaller $\triangle$ ELAs is usually strong where the mountain chains form a barrier for precipitation associated with westerly and northwesterly airflow.

Information on the TL depression $(\Delta \mathrm{TL})$ comes from the palynological literature. Summaries are given by Bortenschlager (1984) and Burga and Perret (1998). The necessary temperature data were taken from Fliri (1974, 1975). They refer to the standard climatic period 1931-60 and are carefully homogenized. For modern precipitation data from high altitudes, we finally relied upon the results of the $(P, T)$ model of Ohmura and others (1992; see below). These are assumed to be more "realistic" than precipitation figures from actual measurements due to the well-known measurement problems at high altitudes (e.g. Frei and Schär, 1998).

Through a complicated biological process, summer temperature determines the TL altitude (Tranquillini, 1979). Therefore, TL fluctuations are excellent parameters for summer temperature fluctuations. During the Younger Dryas, the alpine TL was $400-500 \mathrm{~m}$ lower than today. As it was lowered at the Allerød-Younger Dryas boundary, we can safely assume that its altitude during the Younger Dryas was determined by climate and not by the development of the alpine forest belt during the Late glacial (Patzelt and Bortenschlager, 1976; Bortenschlager, 1984; Burga and Perret, 1998). For our calculations, we used a $\Delta \mathrm{TL}$ value of $-500 \mathrm{~m}$ (Burga and Perret, 1998). If we assume that summer temperature at the TL remains constant, the depression of summer temperature $\left(\Delta T_{\mathrm{S}}\right)$ can be calculated as $\Delta T_{\mathrm{S}}=-\Delta \mathrm{TL}(\partial T / \partial z)$. With a temperature lapse rate $(\partial T / \partial z)$ of $-0.007 \mathrm{~K} \mathrm{~m}^{-1}$, a TL depression of $-500 \mathrm{~m}$ is equivalent to a summer temperature depression of $-3.5 \mathrm{~K}$.

The ELA is determined by the climatic conditions which govern ablation and accumulation. Hence, a vertical shift of the ELA can be caused by changes in both ablation and accumulation. In many statistical glacier-climate models, ablation is parameterized by "summer temperature" at the ELA $\left(T_{\mathrm{S}}\right)$, and accumulation by "precipitation" $(P)$. In this paper, we chose the statistical $(P, T)$ relation of Ohmura and others (1992) and compare the results with those derived from the glacial-meteorological model of Kuhn (1981a). For convenience, the models are referred to below as "OKF model" and "Kuhn model".

Ohmura and others (1992, p. 401) found a non-linear relationship between the free-air summer (June-August) temperature and annual precipitation sums at the ELA, which has the form

$$
P=645+296 T_{\mathrm{S}}+9 T_{\mathrm{S}}^{2},
$$

with a standard error of the estimate of $\pm 200 \mathrm{~mm}$. Summer temperature at the modern ELA $\left(T_{\mathrm{Sm}}\right)$ is calculated in a first step from the standard temperature data provided by Fliri (1974, 1975). Comparison of the standard climatological temperature data with the free-air temperature data used by Ohmura and others (1992) shows that the former must be augmented by $0.7 \mathrm{~K}$ in the central part of the Alps (high ELA) to achieve a comparable dataset, whereas they are more or less similar at the northern slope of the Alps (low ELA). Then precipitation at the modern ELA $\left(P_{\mathrm{m}}\right)$ is calculated with Equation (1). $P_{\mathrm{m}}$ is used as a reference for all subsequent calculations.

Summer temperature at the Egesen-I ELA $\left(T_{\mathrm{SE}}\right)$ is calculated as

$$
T_{\mathrm{SE}}=T_{\mathrm{Sm}}+\Delta T_{\mathrm{S}}+\Delta \mathrm{ELA} \partial T / \partial z .
$$

Precipitation at the Egesen-I ELA $\left(P_{\mathrm{E}}\right)$ is also calculated with Equation (1). Precipitation change $\Delta P$ at the modern ELA can then be calculated as

$$
\Delta P=P_{\mathrm{E}}-\partial P / \partial z \Delta \mathrm{ELA}-P_{\mathrm{m}},
$$

where $\partial P / \partial z$ is the vertical precipitation gradient. For our calculations we chose $\partial P / \partial z$ as $0.33 \mathrm{~mm} \mathrm{~m}^{-1}$, which is slightly higher than the figure given by Fliri (1975).

For comparison, precipitation change was also calculated with the glacial-meteorological model of Kuhn (1981a), which relates energy and mass balance at the equilibrium line. Details can be found in Kuhn (1981a, b, 1989). For our purpose, the model is first used to calculate accumulation changes. If $\Delta c$ denotes the change of accumulation, it can be calculated as

$$
\begin{aligned}
\Delta c= & \frac{\tau}{L_{\mathrm{m}}}\left[-G \delta r+\delta A+\frac{\partial A}{\partial z} \Delta \mathrm{ELA}+\alpha\left(\delta T_{\mathrm{s}}+\frac{\partial T_{\mathrm{s}}}{\partial z} \Delta \mathrm{ELA}\right)\right] \\
& -\left(\frac{\tau}{L_{\mathrm{s}}}-\frac{\tau}{L_{\mathrm{m}}}\right) \delta Q_{\mathrm{L}}-\frac{\partial c}{\partial z} \Delta \mathrm{ELA}
\end{aligned}
$$

where $\tau$ is the duration of the ablation period ( $100 \mathrm{~d}$ ), $L_{\mathrm{m}}$ and $L_{\mathrm{s}}$ are the latent heat of fusion $\left(0.335 \mathrm{MJ} \mathrm{kg}^{-1}\right)$ and of sublimation (2.835 $\mathrm{MJ} \mathrm{kg}^{-1}$ ), respectively, $G$ is the global radiation $\left(20 \mathrm{MJ} \mathrm{m}^{-2} \mathrm{~d}^{-1}\right), r$ is the albedo, $A$ is the atmospheric longwave radiation, $\alpha$ is the turbulent heat-exchange coefficent $\left(1.5 \mathrm{MJ} \mathrm{m}^{-2} \mathrm{~d}^{-1}\right), T_{\mathrm{S}}$ is the air temperature of the ablation period, $Q_{\mathrm{L}}$ is the latent-heat flux and $\partial c / \partial z$ is the vertical accumulation gradient $\left(1 \mathrm{~kg} \mathrm{~m}^{-2} \mathrm{~m}^{-1}\right)$. All changes not incorporated in Equation (4) are considered as zero.

Following Kuhn (1981a), the change in longwave atmospheric radiation is linearized as

$$
\delta A+\frac{\partial A}{\partial z} \Delta \mathrm{ELA}=4 \sigma 273.15^{3}\left(\delta T_{\mathrm{s}}+\frac{\partial T}{\partial z} \Delta \mathrm{ELA}\right),
$$

where $\sigma$ is the Stefan-Boltzmann constant $\left(4.9 \times 10^{-9} \mathrm{MJ} \mathrm{K}^{-4}\right.$ $\left.\mathrm{d}^{-1}\right)$. The change in the latent-heat flux $\delta Q_{\mathrm{L}}$ can be calculated as $\delta Q_{\mathrm{L}}=\delta S\left(L_{\mathrm{s}} \tau\right)$, where $\delta S$ is the change in sublimation $\left(\mathrm{kg} \mathrm{m}^{-2} \mathrm{a}^{-1}\right)$. Finally, the change in precipitation is calculated as $\Delta P=\Delta c / 1.5$ under the assumption that accumulation is $50 \%$ larger than precipitation at the ELA.

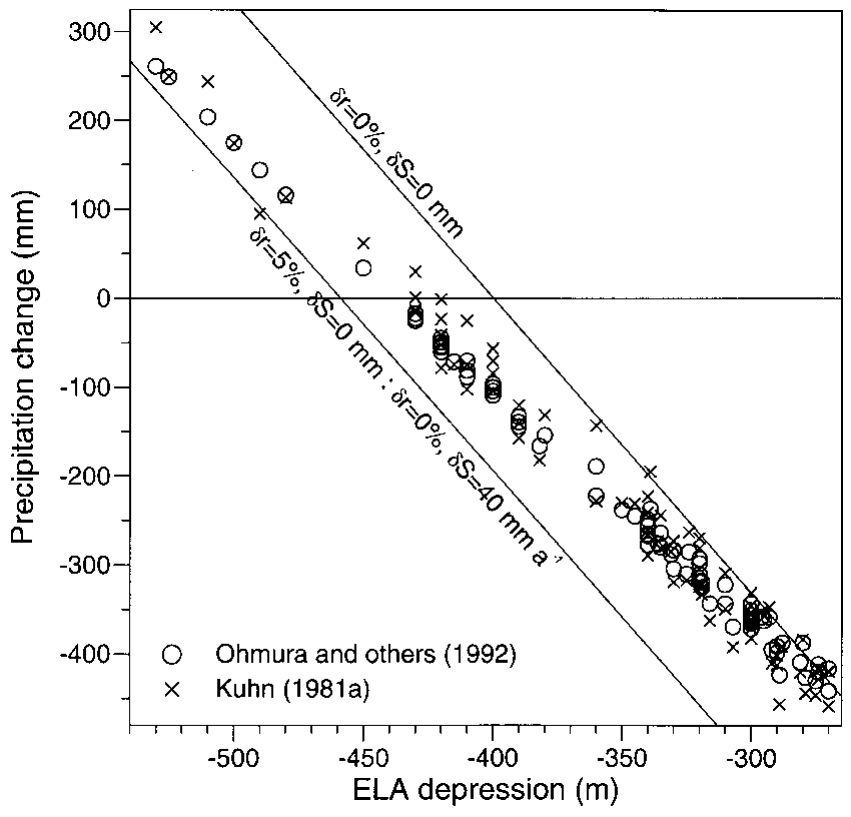

Fig. 1. Relation between early Younger Dryas (Egesen-I) ELA depression and precipitation change $\left(\mathrm{mm} \mathrm{a}^{-1}\right)$. 


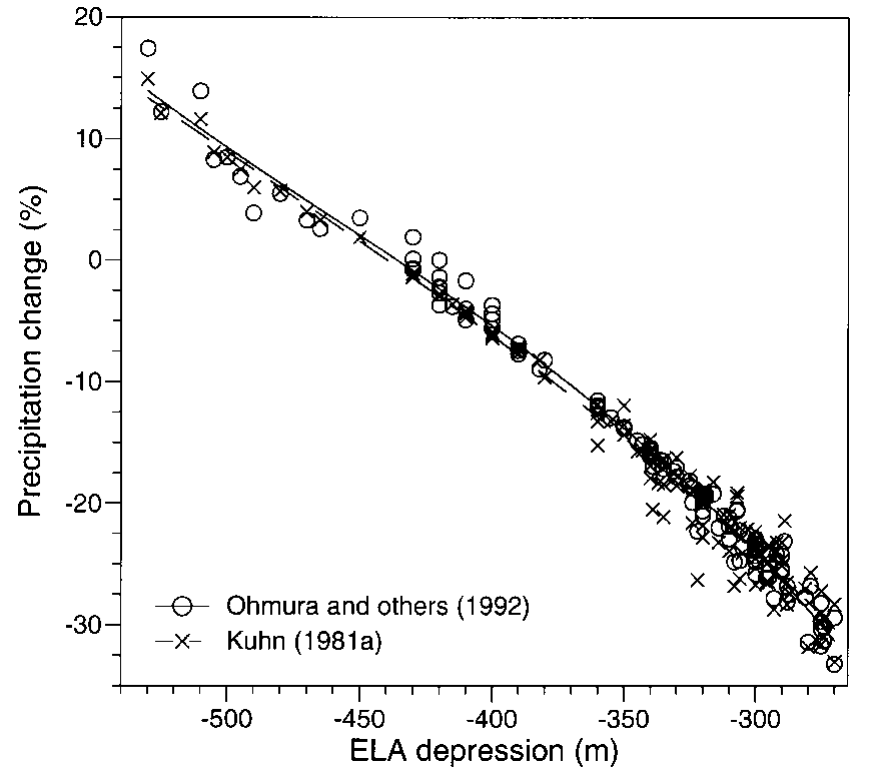

Fig. 2. Relation between early Tounger Dryas (Egesen-I) ELA depression and precipitation change (\%).

\section{DISGUSSION}

The results of our calculations are summarized in Figures 1 and 2. The solid lines in Figure 1 show different scenarios for the Kuhn model (Equation (4)). The data points of the OKF model are close to the Kuhn model, with no changes in albedo and sublimation in those areas where the depression of the ELA is on the order of $-300 \mathrm{~m}$. Closer to the northern slope of the Alps, where $\triangle \mathrm{ELA}$ is in the order of -450 to $500 \mathrm{~m}$, the results of the OKF model suggest that albedo and/or sublimation were slightly higher than can be expected today.

The best correlation between the OKF model and the Kuhn model is achieved if albedo values are gradually increased towards the northern margin of the Alps. We assume that albedo remained unchanged $(\delta r=0)$ in the central part of the Alps (high ELA) and increased by $5 \%$ towards the northern margin (low ELA; $\delta r=0.05$ ), which is equivalent to an increase in evaporation from the glacier surface by $40 \mathrm{~mm} \mathrm{a}^{-1}$. In that case, the correlation coefficient of precipitation change between the two models is 0.995 (Fig. 3).

Figures 1 and 2 show a clear correlation between $\triangle$ ELA and precipitation change. Under the assumptions made above, $\Delta \mathrm{P}$ ranges between $-450 \mathrm{~mm} \mathrm{a}^{-1}(\Delta \mathrm{ELA}=-270 \mathrm{~m})$ and $+250 \mathrm{mma}^{-1}(\Delta \mathrm{ELA}=520 \mathrm{~m})$ or -30 to $-35 \%$ and $+12 \%$, respectively. The central, well-shielded valleys of the Alps were obviously drier than today, whereas areas exposed to westerly and northwesterly airflow seem to have been slightly more humid than today (Fig. 4). The results are broadly similar to those from earlier studies on Younger Dryas precipitation patterns in the Alps, which were based on a different methodology (Kerschner, 1981, 1985). They are at least partially supported by the results from permafrostglacier studies (Haeberli, 1982; Sailer and Kerschner, 1999) and the palaeoclimatic interpretation of other glaciological parameters from Late-glacial glaciers in the Alps (Maisch and Haeberli, 1982). They also agree well with the qualitative results from palaeobotanical studies (cf. Burga and Perret, 1998). The spatial pattern of ELA depressions and precipitation change is surprisingly similar to the present-day precipitation pattern, as it is caused by cyclonic westerly and northwesterly airflow (Fliri and Schüepp, 1983). This supports

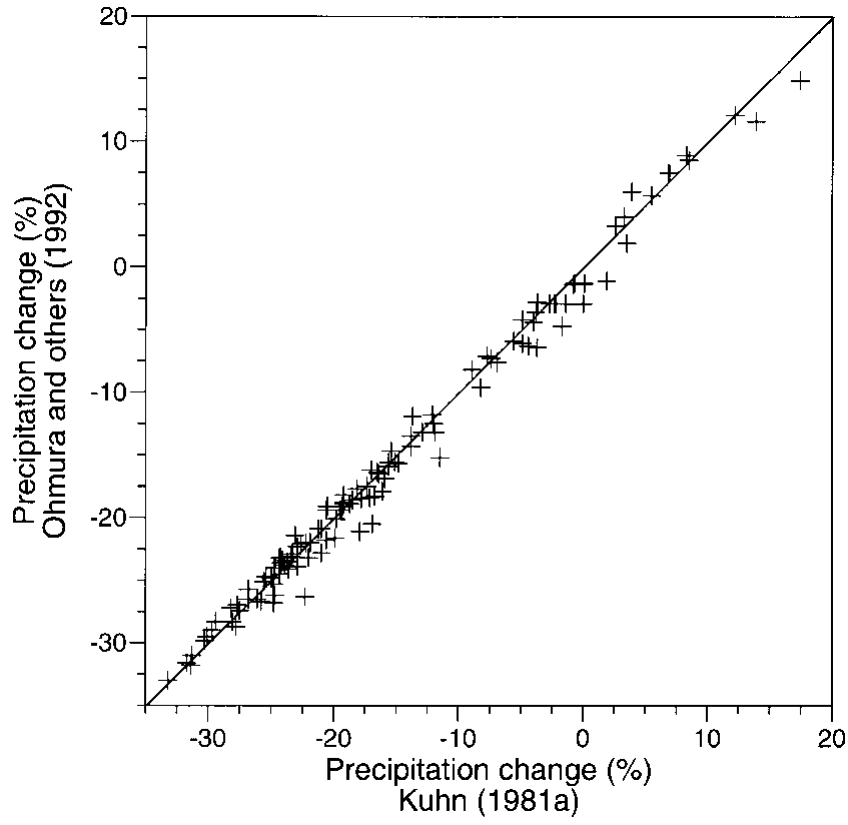

Fig. 3. Correlation between results from the models by Ohmura and others (1992) and Kuhn (1981a).

the results from AGCMs of the Younger Dryas (Isarin and others, 1997; Renssen, 1997) which suggest a more zonal circulation over northwestern and western Europe during the Younger Dryas.

Some possible error sources should be mentioned. One of them is the possible misinterpretation of the glacial-geomorphological record. This can be overcome only by an increase in the number of absolutely dated moraines. However, present results suggest that the assignment of moraines to the Egesen Stadial with field methods is broadly correct. From a more climatological point of view, all comparisons between past and present precipitation patterns suffer from our lack of knowledge of the present-day precipitation above TL in the Alps. Therefore, the modern precipitation at the ELA, as calculated from the OKF model, is used as reference. A further source of uncertainties is the assumption of a spatially constant TL depression and hence summer temperature depression. If we assumed that $\Delta \mathrm{TL}$ was $-500 \mathrm{~m}\left(\Delta \mathrm{T}_{\mathrm{S}}=-3.5 \mathrm{~K}\right)$ in the north and only $-400 \mathrm{~m}$ in the central Alps $\left(\Delta T_{\mathrm{S}}=\right.$ $-2.8 \mathrm{~K}$ ), precipitation change along the northern slope would remain the same as above, but only on the order of -10 to $-15 \%$ in the central valleys. It should also be kept in mind that spatially constant vertical lapse rates of precipitation (OKF model) and accumulation (Kuhn model) are only first approximations. In reality, vertical and horizontal precipitation gradients in the Alps are inseparably linked to each other and strongly influenced by the precipitation regime and synoptic-scale airflow (e.g. Fliri, 1975; Frei and Schär, 1998). The influence of precipitation change on the inferred figures is, however, difficult to quantify. Some cautious experiments with different scenarios showed that the possible error in precipitation change should be in the order of $\pm 50 \mathrm{~mm} \mathrm{a}^{-1}$ in the central Alps and $\pm 100 \mathrm{mma}^{-1}$ along the northern slope, which is less than the standard error of the OKF model.

\section{GONGLUSIONS}

The results of our calculations show that the statistical glacier-climate model of Ohmura and others (1992) and the 


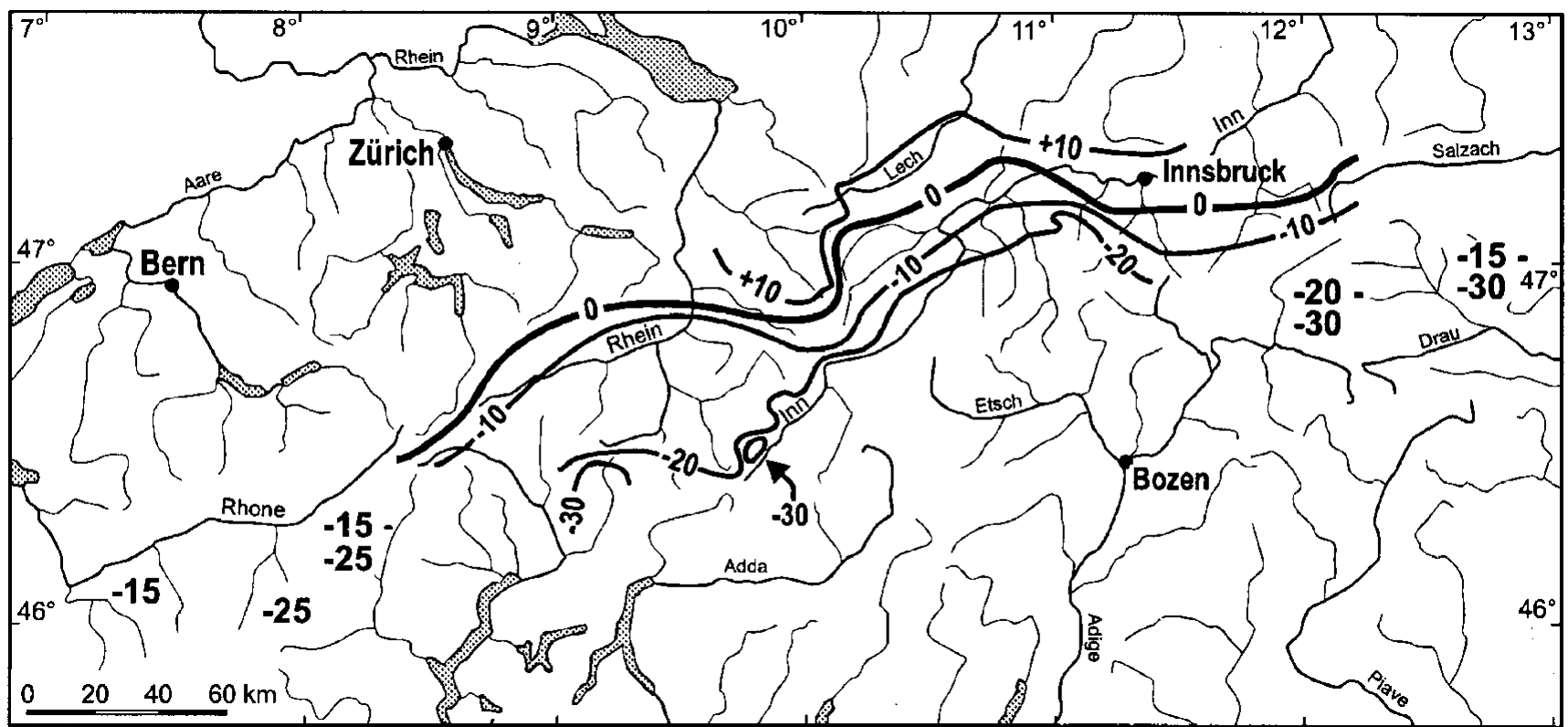

Fig. 4. Tentative map of early Younger Dryas (Egesen-I) precipitation change (\%) in the Alps between Rhone valley to the west and Hohe Tauern mountains to the east.

glacial-meteorological model of Kuhn (1981a) lead to similar results. They are useful tools for the inference of palaeo-precipitation patterns from ELA depressions, if independent data for summer temperature depression are available. In the case of the Younger Dryas in the Alps, TL depression as provided by palynology seems to be a reliable input variable for the calculation of summer temperature change.

The regional pattern of precipitation change shows that the contrast between the northern margin of the Alps and the central, more shielded valleys was stronger during the early Younger Dryas than today. In particular, those areas which are well exposed to westerly-to-northwesterly airflow seem to have received more precipitation than today. This suggests a higher frequency of westerly and northwesterly airflow patterns in the Alps during the early Younger Dryas. Our present results support those from AGCMs, which point towards a more zonal circulation pattern over western and northwestern Europe during the Younger Dryas.

There are still considerable gaps in our knowledge of Younger Dryas ELA depressions in wide areas of the Alps, particularly in the western and southern Alps. Future fieldwork should concentrate on areas closer to the Po plain in northern Italy and to the Mediterranean Sea.

\section{AGKNOWLEDGEMENTS}

This study was partly supported by the Austrian "Fonds zur Förderung der wissenschaftlichen Forschung" under grant P12600-GEO. We gratefully acknowledge the help of A. Hertl of Universität Innsbruck, who supplied unpublished ELA depression data from his fieldwork in the Silvretta mountains.

\section{REFERENCES}

Bortenschlager, S. 1984. Beiträge zur Vegetationsgeschichte Tirols I. Inneres Ötztal und unteres Inntal. Berichte des Naturwissenschaftlich-Medizinischen Vereins in Innsbruck 71, 19-56.

Burga, C. and R. Perret. 1998. Vegetation und Klima der Schweiz seit dem jüngeren Eiszeitalter. Thun, Ott.

Fliri, F. 1974. Niederschlag und Lufttemperatur im Alpenraum. Wiss. Alpen- vereinsh. 24.

Fliri, F. 1975. Das Klima der Alpen im Raume von Tirol. Innsbruck-München, Universitätsverlag Wagner. (Monographien zur Landeskunde Tirols, Vol. 1.)

Fliri, F. and M. Schüepp. 1983. Synoptische Klimatographie der Alpen zwischen Mont Blanc und Hohen Tauern. Wiss. Alpenvereinsh. 29.

Frei, Ch. and Ch. Schär. 1998. A precipitation climatology of the Alps from high-resolution rain-gauge observations. Int. F. Climatol., 18(8), 873-900.

Furrer, G., C. Burga, M. Gamper, H. Holzhauser and M. Maisch. 1987. Zur Gletscher-, Vegetations- und Klimageschichte der Schweiz seit der Späteiszeit. Geogr. Helv., 42(2), 61-91.

Groß, G. 1987. Der Flächenverlust der Gletscher in Österreich 1850-19201969. Z. Gletscherkd. Glazialgeol., 23(2), 131-141.

Groß, G., H. Kerschner and G. Patzelt. 1977. Methodische Untersuchungen über die Schneegrenze in alpinen Gletschergebieten. Z. Gletscherkd. Glazialgeol., 12 (2), 1976, 223-251.

Haeberli, W. 1982. Klimarekonstruktionen mit Gletscher-Permafrostbeziehungen. Basler Beitr. Physiogeogr. 4, 9-17.

Heuberger, H. 1966. Gletschergeschichtliche Untersuchungen in den Zentralalpen zwischen Sellrain- und Ötztal. Wiss. Alpenvereinsh. 20.

Holzhauser, H. P. 1984. Zur Geschichte der Aletschgletscher und des Fieschergletschers. Zürich, Universität Zürich. Geographisches Institut. (Physische Geographie 13.)

Isarin, R. F. B., H. Renssen and E. A. Koster. 1997. Surface wind climate during the Younger Dryas in Europe as inferred from aeolian records and model simulations. Palaeogeogr., Palaeoclimatol., Palaeoecol., 134(1-4), 127-148.

Ivy-Ochs, S., Ch. Schlüchter, P. Kubik and J. Beer. 1995. Das Alter der Egesenmoräne am Julierpass. Oberflächenalterbestimmungen in Graubünden (Schweiz) mit den kosmogenen Radionukliden ${ }^{10} \mathrm{Be}$ und ${ }^{26} \mathrm{Al}$. Geowissenschaften, 13(8-9), 313-315.

Ivy-Ochs, S., Ch. Schlüchter, P.W. Kubik, H.-A. Synal, J. Beer and H. Kerschner. 1996. The exposure age of an Egesen moraine at Julier Pass, Switzerland, measured with the cosmogenic radionuclides ${ }^{10} \mathrm{Be},{ }^{26} \mathrm{Al}$ and ${ }^{36} \mathrm{Cl}$. Eclogae Geol. Helv., 89(3), 1049-1063.

Kerschner, H. 1978. Untersuchungen zum Daun- und Egesenstadium in Nordtirol und Graubünden (methodische Überlegungen). Geogr. Fahresber. Österr., 36, 1975-1976, 26-49.

Kerschner, H. 1981. Outlines of the climate during the Egesen Advance (Younger Dryas, 11000-10000 BP) in the central Alps of the western Tyrol, Austria. Z. Gletscherkd. Glazialgeol., 16(2), 1980, 229-240.

Kerschner, H. 1985. Quantitative palaeoclimatic inferences from lateglacial snowline, timberline and rock glacier data, Tyrolean Alps, Austria. Z. Gletscherkd. Glazialgeol., 21, 363-369.

Kuhn, M. 198la. Climate and glaciers. International Association of Hydrological Sciences Publication 131 (Symposium at Canberra 1979 - Sea Level, Ice and Climatic Change), 3-20.

Kuhn, M. 1981b. Die Reaktion der Schneegrenze auf Klimaschwankungen. Z. Gletscherkd. Glazialgeol., 16(2), 1980, 241-254.

Kuhn, M. 1989. The response of the equilibrium line altitude to climatic fluctuations: theory and observations. In Oerlemans, J., ed. Glacier fluctuations 
and climatic change. Dordrecht, etc., Kluwer Academic Publishers, 407-417.

Maisch, M. 1992. Die Gletscher Graubündens: Rekonstruktion und Auswertung der Gletscher und deren Veränderungen seit dem Hochstand von $1850 \mathrm{im}$ Gebiet der östlichen Schweizer Alpen (Bündnerland und angrenzende Regionen). Zürich, Universität Zürich. Geographisches Institut. (Physische Geographie 33.)

Maisch, M. and W. Haeberli. 1982. Interpretation geometrischer Parameter von Spätglazialgletschern im Gebiet Mittelbünden, Schweizer Alpen. In Gamper, M., ed. Beiträge zur Quartärforschung in der Schweiz. Universität Zürich. Geographisches Institut, 111-126. (Physische Geographie 1.)

Mayr, F. and H. Heuberger. 1968. Type areas of late glacial and post-glacial deposits in Tyrol, Eastern Alps. In Richmond, G. M., ed. Glaciations of the Alps. Boulder, CO, University of Colorado. INQUA International Congress, 143-165. (Series in Earth Sciences 7.)

Müller, H.-N., H. Kerschner and M. Küttel. 1981. Gletscher- und vegetationsgeschichtliche Untersuchungen im Val de Nendaz (Wallis) - ein Beitrag zur alpinen Spätglazialchronologie. Z. Gletscherkd. Glazialgeol., 16(1), 1980, 61-84.

Ohmura, A., P. Kasser and M. Funk. 1992. Climate at the equilibrium line of glaciers. F. Glaciol., 38(130), 397-411.

Patzelt, G. 1972. Die spätglazialen Stadien und postglazialen Schwankungen von Ostalpengletschern. Ber. Dtsch. Bot. Ges. 85, 47-57.

Patzelt, G. and S. Bortenschlager. 1973. Die postglazialen Gletscher- und Klimaschwankungen in der Venedigergruppe (Hohe Tauern, Ostalpen). Z. Geomorphol., Supplementband 16, 25-72.

Patzelt, G. and S. Bortenschlager. 1976. Spät- und Postglazial im Ötztal und Inntal (Ostalpen, Tirol). In Frenzel, B., ed. Führer zur Exkursionstagung 513 September 1976 des IGCP-Projekts 31/1/24 "Quaternary Glaciations in the Northern Hemisphere”. International Geological Correlation Program, 185-197.

Renssen, H. 1997. The climate during the Younger Dryas stadial. Utrecht, Koninklijk Nederlands Aardrijkskundig Genootschap. (Nederlandse Geografische Studies 217.

Sailer, R. and H. Kerschner. 1999. Equilibrium-line altitudes and rock glaciers during the Younger Dryas cooling event, Ferwall Group, western Tyrol, Austria. Ann. Glaciol., 28, 141-145.

Tranquillini, W. 1979. Physiological ecology of the Alpine timberline: tree existence at high altitudes with special reference to the European Alps. Berlin, Springer. (Ecological Studies 31.)

\section{APPENDIX}

\section{ADDITIONAL SOURGES}

Aeschlimann, H. 1983. Zur Gletschergeschichte des italienischen Mont Blanc Gebiets: Val Veni - Val Ferret - Ruitor. (Inaug. Diss., Universität
Zürich.)

Bless, R. 1984. Beiträge zur spät-und postglazialen Geschichte der Gletscher im nordöstlichen Mont Blanc Gebiet. Zürich, Universität Zürich. Geographisches Institut. (Physische Geographie 15.)

Buchenauer, H.W. 1990. Gletscher- und Blockgletschergeschichte der westlichen Schobergruppe (Osttirol). Marburg. Geogr. Schr. 117.

Damm, B. 1996. Gletscher-, Landschafts- und Klimaentwicklung in der Rieserfernergruppe (Tirol) seit dem Spätglazial. Göttingen, Universität Göttingen. Geographisches Institut. (Göttinger Geographische Abhandlungen 104.

Hirtlreiter, G. 1992. Spät- und postglaziale Gletscherschwankungen im Wettersteingebirge und seiner Umgebung. (Ph.D. thesis, Universität München.)

Kerschner, H. 1979. Spätglaziale Gletscherstände im inneren Kaunertal (Ötztaler Alpen). Innsbruck. Geogr. Stud. 6, 235-247.

Kerschner, H. 1993. Späteiszeitliche Gletscherstände im südlichen Karwendel bei Innsbruck, Tirol. Innsbruck. Geogr. Stud. 20, 47-55.

Kerschner, H. and E. Berktold. 1982. Spätglaziale Gletscherstände und Schuttformen im Senderstal, nördliche Stubaier Alpen, Tirol. Z Gletscherkd. Glazialgeol., $17(2), 1981,125-134$.

Maisch, M. 1981. Glazialmorphologische und gletschergeschichtliche Untersuchungen im Gebiet zwischen Landwasser- und Albulatal (Kt. Graubünden, Schweiz). Zürich, Universität Zürich. Geographisches Institut. (Physische Geographie 3.)

Müller, H.N. 1984. Spätglaziale Gletscherschwankungen in den westlichen Schweizer Alpen (Simplon-Süd und Val de Nandaz, Wallis) und im nordisländischen Tröllaskagi-Gebirge (Skidadalur). Näfels, Küng.

Patzelt, G. 1983. Die spätglazialen Gletscherstande im Bereich des Mieselkopfes und im Arztal, Tuxer Voralpen, Tirol. Innsbruck. Geogr. Stud. 8, 35-44.

Renner, F. 1982. Beiträge zur Gletschergeschichte des Gotthardgebietes und dendroklimatologische Analysen an fossilen Hölzern. Zürich, Universität Zürich. Geographisches Institut. (Physische Geographie 8.)

Suter, J. 1981. Gletschergeschichte des Oberengadins: Untersuchungen von Gletscherschwankungen in der Err-fulier-Gruppe. Zürich, Universität Zürich. Geographisches Institut. (Physische Geographie 2.)

Suter, J. and B. Gamper-Schollenberger. 1982. Gletscher-, Vegetations- und Klimageschichte im Oberengadin. In Maisch, M. and J. Suter, eds. Exkursionsführer, Teil A: Ostschweiz (Hauptversammlung DEUQUA Zürich). Zürich, Universität Zürich. Geographisches Institut, 14-30. (Physische Geographie 6.)

Vögele, A. 1984. Untersuchungen zur Geomorphologie und jungquartären Talgeschichte des Dischma (Davos, Kt. Graubünden). Zürich, Universität Zürich. Geographisches Institut. (Physische Geographie 14.)

Vuagneux, R. 1983. Glazialmorphologische und gletschergeschichtliche Untersuchungen im Gebiet des Flüelapass (Kt. Graubünden, Schweiz). Zürich, Universität Zürich. Geographisches Institut. (Physische Geographie 10.) 